\title{
CHEMICAL VALORIZATION OF CELLULOSE FROM LIGNOCELLULOSIC BIOMASS: A STEP TOWARDS SUSTAINABLE DEVELOPMENT
}

\author{
RAMANDEEP KAUR and PUNEET KAUR \\ Department of Chemistry, Punjab Agricultural University, Ludhiana-141004, India \\ × Corresponding author: Ramandeep Kaur, ramanhunjan@pau.edu
}

Received June 17, 2020

\begin{abstract}
The potential of non-edible lignocellulosic biomass paves the path to sustainable economy. A large number of valueadded products have been synthesized by the fractionation of the major components of biomass, i.e. cellulose, hemicelluloses and lignin. Cellulose, the most abundant biopolymer on earth, serves as a starting material for the synthesis of various platform chemicals, such as sorbitol, 5-hydroxylmethylfurfural (HMF), dimethylfuran and levulinic acid. Hydrogels and aerogels fabricated from cellulose, modified cellulose or nanocellulose have proved valuable in a wide range of such as biomedical, food and technological applications. Cellulose-based polymers or bioplastics also emerged as an alternative to fossil fuel-based polymers. In this review, chemical paths to valorize plant cellulose for producing various value-added products have been discussed. The major challenge for valorization is the development of novel and green synthesis methods with simultaneous focus on an integrated approach.
\end{abstract}

Keywords: cellulose, valorization, lignocellulosic biomass, platform chemicals, bioplastics

\section{INTRODUCTION}

Industrialization prospered due to progress in science and technology and, though it improved the standards of living, it also turned out to be a major contributing factor towards the exploitation and depletion of natural resources, be it land, water, air, soil or fossil fuels. The demand for natural sources of energy, i.e. coal, oil, natural gas, biomass, heat, hydroelectric and nuclear power plants, is increasing with growing population (Fig. 1), thus making sustainable development a major challenge for the era. The concept of sustainable development is not just limited to effective utilization of present energy resources for meeting the needs of future generations, but includes all activities that could make a difference to society, its standards of living and global economy as a whole. The global energy consumption statistics of the years 20172018 shows an acceleration of $2.3 \%$ in energy consumption in 2018; thus highlighting the need for a shift from a fossil fuel-based economy to a biomass-based economy. ${ }^{1}$ This shift would not only combat the issues related to depleting fossil fuels and their increasing prices, but would also lend a helping hand for achieving long-term development goals by providing alternatives for the generation of energy, biofuels, biomaterials and value-added chemicals. The process involving the conversion of biomass to valueadded chemicals, polymers, and biofuels is termed as biorefinery.

Lignocellulosic biomass, the production of which exceeds 933 million tonnes per year throughout the world, ${ }^{2}$ serves as a natural, inexpensive, renewable and eco-friendly raw material for the industrial sector of economy. A small part of biomass is utilized as animal forage, as raw material for the paper industry, or in energy production, the rest being burnt as the most common method of disposal. Therefore, the valorization of biomass becomes essential from economic, environmental and sustainability perspectives. Lignocellulosic biomass, which is basically plant dry matter, can be broadly categorized as agricultural (straw, bagasse, stover) and forestry waste, virgin biomass (trees, bushes and grass) and energy crops. ${ }^{3}$ The biomass source, the plant type, species, and even age will effect the percent chemical composition of its constituent polymers. Table 1 summarizes the 
chemical composition of common lignocellulosic materials.

Lignocellulosic biomass is structurally composed of three biopolymers - cellulose, hemicelluloses and lignin, with small amounts of non-structural compounds - extractives and ash. Cellulose is generally the most abundant component of biomass on the earth, followed by hemicelluloses and lignin. It is a linear, crystalline homopolymer of glucose bound to amorphous hemicelluloses via hydrogen bonding. Hemicellulose, a heteropolymer, comprises varying proportions of five and six carbon sugars, like xylose, arabinose, mannose, galactose and glucose, based upon the plant type and the procedure of extraction. Lignin, a threedimensional, complex, aromatic, hydrophobic, phenolic polymer made up of three aromatic alcohols - coniferyl, sinapyl and p-coumaryl, entangles the carbohydrate polymers by forming a protective sheath; it also acts as a physical barrier to the accessibility of enzymes, thereby making hydrolysis and hence their separation difficult. The high crystallinity of cellulose, the hydrophobicity of lignin and its protective seal around cellulose-hemicelluloses polymers, as well as the silica content of biomass, result in its recalcitrance. ${ }^{6}$ Extractives are generally organic compounds containing terpenes, waxes, oils, gums, fats, proteins etc. and ash constitutes the inorganic portion of biomass. ${ }^{11}$ Pretreatment is the foremost step to valorize biomass, while the type of pretreatment affects the nature and content of the fraction isolated and the yield of the final product. Several research papers and review articles classify pretreatments into four categories, i.e. physical, chemical, biological and physiochemical. ${ }^{12-14}$ The choice of pretreatment is governed by the nature of the biomass material, each pretreatment having its own advantages and disadvantages. In this article, the conversion potential of the most abundant natural polymer, i.e. cellulose, into various high-value materials is reviewed.

\section{Structure of cellulose}

Cellulose (Fig. 2), a stable homopolymer of glucose, serves as an important architectural unit responsible for the rigidity of the plant cell wall. It has the molecular formula $\left(\mathrm{C}_{6} \mathrm{H}_{10} \mathrm{O}_{5}\right)_{\mathrm{n}}$, where the value of $\mathrm{n}$ ranges from about a thousand to over ten thousand glucose units joined end to end with $\beta-1,4$ glycosidic bonds. The two ends of the cellulose chain are chemically different, so that at one end the anomeric carbon of the glucopyranose unit is free, while the other end has the anomeric carbon involved in a glycosidic linkage.

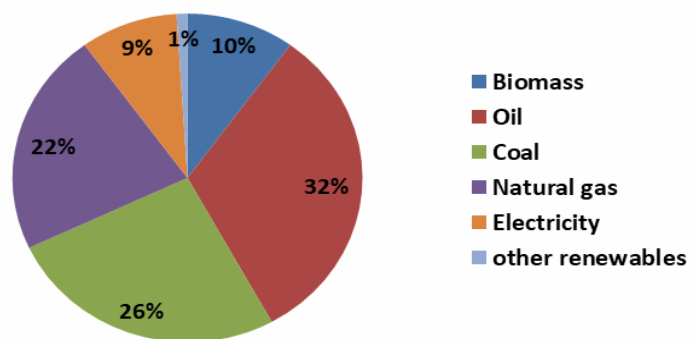

Figure 1: Global demand of natural energy sources (data for 2018) ${ }^{1}$

Table 1

Percent composition of cellulose, hemicelluloses and lignin in the most common lignocellulosic materials

\begin{tabular}{|c|c|c|c|}
\hline Lignocellulosic material & Cellulose (\%) & Hemicelluloses (\%) & Lignin (\%) \\
\hline Eucalyptus ${ }^{4}$ & 54 & 18 & 22 \\
\hline Pine $^{4}$ & $42-50$ & $24-27$ & 20 \\
\hline Miscanthus giganteus ${ }^{5}$ & $37-45$ & $19-25$ & $17-21$ \\
\hline Rice husk $^{6}$ & 40 & 21 & 22 \\
\hline Rice straw $^{7}$ & 36 & 24 & 16 \\
\hline Wheat straw ${ }^{7}$ & 38 & 27 & 18 \\
\hline Corn cobs ${ }^{8}$ & 44 & 39 & 12 \\
\hline Sugarcane bagasse $^{9}$ & 42 & 28 & 19 \\
\hline Sweet sorghum ${ }^{10}$ & 46 & 28 & 11 \\
\hline
\end{tabular}




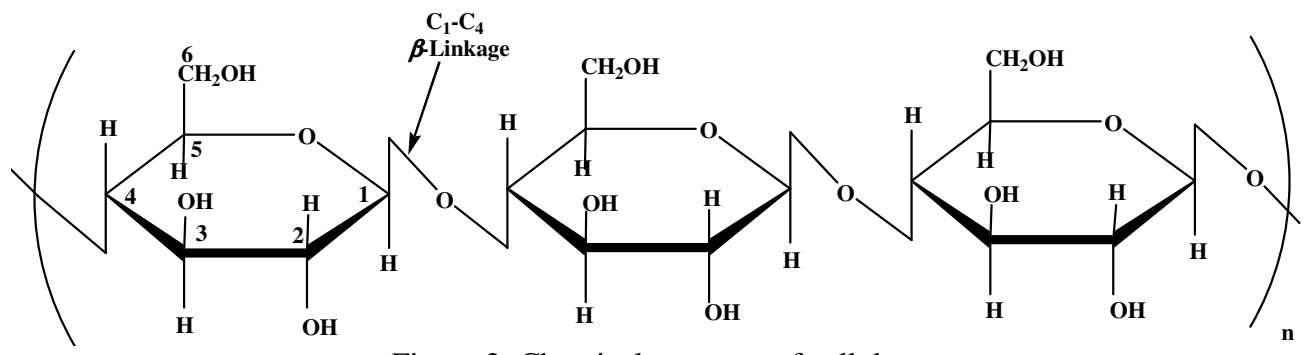

Figure 2: Chemical structure of cellulose

The presence of three free hydroxyl groups, i.e. one primary hydroxyl group in the methylol group at C-6 position and two secondary hydroxyl groups at C-3 and C-4 in each glucose unit, enables the linear cellulose chain to form intermolecular and intramolecular hydrogen bonds.

The hydrogen bonds between the cellulose chains and van der Waals forces between the glucose units lead to the formation of crystalline regions in cellulose. ${ }^{15}$ The intramolecular hydrogen bonding between the adjacent glucose residues of the linear cellulose chain makes it highly stable, while the intermolecular hydrogen bonding among the glucose units of two different cellulose chains result in a parallel stacked structure, so that about 20-100 cellulose chains group to form cellulose microfibrils. These microfibrils ultimately assemble to form cellulose fibers or cellulose macrofibers exhibiting high tensile strength and crystallinity. ${ }^{16}$ This extensively hydrogen bonded network in cellulose renders it insoluble in water and most solvents. Initially, the dissolution of cellulose emerged as an important barrier in its valorization, but recently, it has been overcome by the use of alkalies, ${ }^{17}$ the $\mathrm{NaOH} /$ urea aqueous system, ${ }^{18}$ ionic liquids etc. ${ }^{19}$

\section{Isolation of cellulose}

Cellulose is physically and chemically surrounded by hemicelluloses and lignin, the links forming a lignocellulose matrix. Pretreatment is thus necessary before an attempt is made to isolate the cellulose. The cellulose content, the nature of the pretreatment and the extraction procedure will differ depending on the source of biomass. Cellulose fibers have been extracted from rice husk using alkali and bleaching treatments. ${ }^{20}$ Cellulose pulp had been extracted from rice husk by a multi-step process, where first the husk was pretreated with an alkali solution to remove hemicelluloses and lignin, then two-step bleaching with hydrogen peroxide/tetraacetylethylenediamine, followed by another delignification step using a mixture of acetic and nitric acids. ${ }^{21}$ Green extraction of cellulose from oil palm empty fruit bunch fibers has been carried out using autoclave and ultrasonic based treatments. The alkaline hydrogen peroxide, i.e. $\mathrm{NaOH}-\mathrm{H}_{2} \mathrm{O}_{2}$ mixture, and the sodium chlorite delignified material were ultrasonicated and autoclaved separately. Cellulose yields of $49 \%$ and $64 \%$ were obtained using the ultrasonic and autoclave based treatments, respectively. ${ }^{22}$ A cellulose yield of about $74.70 \%$ was obtained when date palm rachis was subjected to low concentration acidalkali treatment. This treatment successfully removed a considerable amount of hemicelluloses and lignin, and provided highly crystalline cellulose. $^{23}$

Ionic liquids (ILs), existing as ion pairs, have emerged as green solvents for pretreatment of biomass. The most common examples include salts with organic cations, i.e. alkylimidazolium, alkylpyridinium, tetraalkylammonium or tetraalkylphosphonium, and inorganic anions, i.e. hexafluorophosphate, tetrafluoroborate or several low melting chlorides, bromides and iodides. ${ }^{24}$ ILs have been extensively used for the extraction of biomass due to their unique properties, such as low melting points (below $100{ }^{\circ} \mathrm{C}$ ), high polarities, high thermal stabilities, negligible vapour pressure etc. ${ }^{25}$ Ionic liquids tend to compete with hydrogen bonds in the cellulose chain, causing disruption of the hydrogen bonded network; thereby, resulting in cellulose dissolution. The fractionation of hardwood and softwood species has been carried out using an ionic liquid based microwave treatment. ${ }^{26}$ The extraction of cellulose from agricultural waste biomass was carried out using a choline based basic ionic liquid. ${ }^{27}$ Information on cellulose 
extraction by ILs, the mechanism of dissolution of cellulose in ILs, the benefits associated with IL pretreatments in an integrated approach has been provided by a number of research papers and review articles. ${ }^{24,25,27,28}$

\section{VALORIZATION ROUTES Bioplastics}

Bioplastics are environment-friendly biopolymers derived from biomass that serve as an alternative to fossil fuel-based polymers. Bioplastics can be both biodegradable and nonbiodegradable, where biodegradable plastics are only those whose degradation occurs as a result of the natural action of microorganisms, such as bacteria, fungi and algae, in a limited period of time, without affecting ecosystems or the environment. ${ }^{29}$ They find application in agriculture, medicine, food packaging industries, electronics etc. ${ }^{30}$

Bioplastics have certain drawbacks including thermal instability, high vapour content, brittleness etc.; therefore, physical or chemical modification, blending, coating and addition of nanoparticles are carried out to improve their properties. ${ }^{31}$ Cellulose-based plastics include cellulose or cellulose derivatives based polymers, nanocellulose derived polymers and those obtained after polymerization of platform chemicals obtained from cellulose. ${ }^{32}$
Bilo et $a l .{ }^{31}$ prepared cellulose-based bioplastic from rice straw by pretreatment using a Naviglio extractor, followed by treatment with trifluoroacetic acid for solubilizing cellulose. The bioplastic film obtained after evaporation of the solvent was found to have good mechanical property (comparable to thermoplastic polystyrene and polyvinyl chloride), flexibility and exhibited dual shape memory effect. Also, the synthesized bioplastic was found to degrade in soil within 105 days and had comparable energy and $\mathrm{CO}_{2}$ footprint production as other thermoplastics.

\section{Chemical derivatives of cellulose}

Chemical modifications improve the properties of cellulose for diversifying its fields of application. A number of industrially important cellulose derivatives have been prepared by chemical modification of free hydroxyl groups to improve properties such as thermal stability, mechanical strength and solubility. The most common modifications of cellulose involve the synthesis of cellulose esters and ethers prepared homogeneously or heterogeneously (Table 2). Many important cellulose modifications carried out using mineral and organic acids, bases, oxidizing agents, organic compounds, etc. have been reviewed. ${ }^{40,41}$

Table 2

Some important cellulose esters and ethers

\begin{tabular}{|c|c|c|}
\hline[ & $\bigcap_{\mathrm{OR}} \mathrm{O}_{\mathrm{n}}$ & ellulose \\
\hline Modified cellulose & Reagent & $\mathrm{R}$ \\
\hline \multicolumn{3}{|l|}{ Esters } \\
\hline Cellulose acetate ${ }^{33,34}$ & Acetic anhydride/acetic acid & $\mathrm{H}$ or $-\mathrm{COCH}_{3}$ \\
\hline Cellulose nitrate ${ }^{35}$ & Sulfuric-nitric acid mixture & $\mathrm{H}$ or $-\mathrm{NO}_{2}$ \\
\hline Cellulose sulfate ${ }^{36}$ & $\begin{array}{l}\text { Sulfur trioxide/pyridine in } \mathrm{N}, \mathrm{N}- \\
\text { dimethylacetamide/LiCl }\end{array}$ & $\mathrm{H}$ or $-\mathrm{SO}_{3}$ \\
\hline \multicolumn{3}{|l|}{ Ethers } \\
\hline Methyl cellulose $^{37}$ & $\mathrm{CH}_{3} \mathrm{I} / \mathrm{NaOH}$ & $\mathrm{H}$ or $-\mathrm{CH}_{3}$ \\
\hline Ethyl cellulose ${ }^{34}$ & $\mathrm{C}_{2} \mathrm{H}_{5} \mathrm{X} /$ ethanol-water where $\mathrm{X}=\mathrm{Cl}, \mathrm{Br}$ & $\mathrm{H}$ or $-\mathrm{C}_{2} \mathrm{H}_{5}$ \\
\hline $\begin{array}{l}\text { Carboxymethyl } \\
\text { cellulose }^{33,34}\end{array}$ & $\begin{array}{l}\text { Sodium monochloroacetate/ } \mathrm{NaOH} \text { or ethanol/water } \\
\text { or dimethylsulfoxide/ tetrabutylammonium fluoride }\end{array}$ & $\mathrm{H}$ or $-\mathrm{CH}_{2} \mathrm{COO}^{-} \mathrm{Na}^{+}$ \\
\hline Hydroxypropyl cellulose ${ }^{38}$ & Propylene oxide, $\mathrm{NaOH}$ & $\mathrm{H}$ or $-\mathrm{CH}_{2} \mathrm{CH}(\mathrm{OH}) \mathrm{CH}_{3}$ \\
\hline Benzyl cellulose ${ }^{39}$ & Benzyl chloride/ $\mathrm{NaOH}$ & $\mathrm{H}$ or $-\mathrm{CH}_{2} \mathrm{C}_{6} \mathrm{H}_{5}$ \\
\hline
\end{tabular}


Another important modification is the oxidation of hydroxyl groups of cellulose to aldehydes, ketones and carboxylic acids. The oxidation of cellulose using sodium periodate breaks the $\mathrm{C}_{2}-\mathrm{C}_{3}$ bond of the glucose subunit, resulting in 2,3-dialdehyde cellulose, which upon further treatment with $\mathrm{NaClO}_{2}$ forms 2,3dicarboxycellulose. $^{42,43}$ Selective oxidation of primary hydroxyl groups of cellulose to carboxylate groups has been carried out by a 2,2,6,6-tetramethylpiperidine-1-oxyl radical (TEMPO)-mediated system. ${ }^{44,45}$ These derivatives find a variety of uses as emulsion stabilizers, dispersants, thickening agents, food packaging materials, drug carriers, thermoplastics, gels, films, binders etc. ${ }^{40,46,47}$ Apart from these, cellulose can be modified through graft copolymerization and crosslinking (hydrogels and aerogels).

Grafting of monomers onto cellulose is an important way to modify cellulose. In this process, side chain grafts are covalently attached to the backbone of cellulose to form a branched copolymer. ${ }^{48}$ The grafting can be performed both in heterogeneous and in homogeneous medium. Under heterogeneous conditions, grafting is carried out using a suitable initiator, such as ceric ammonium nitrate, various persulfates, azobisisobutyronitrile or Fenton reagent. ${ }^{41} \mathrm{~A}$ number of research papers and review articles have mentioned the most important monomers used for grafting cellulose, such as acrylic acid, methacrylic acid, hydroxyethyl methacrylate, acrylamide, $\quad \mathrm{N}, \mathrm{N}$-methylene-bis-acrylamide, methacrylamide, acrylonitrile, N-vinylpyrrolidone, styrene. ${ }^{41,48,49}$

Hydrogels are polymeric networks with significant water retention capability in their interstitial sites. The absorption of water in these structures occurs due to the presence of hydrophilic groups in the polymeric backbone. On the other hand, the dissolution of water is prevented through crosslinks between the chains. ${ }^{50}$ Hydrogels can be synthesized from natural and synthetic polymers through physical and chemical crosslinking reactions. Natural polymer-based hydrogels have been fabricated due to the increasing demand for environmentally friendly products. Extensive research has been performed on cellulose-based hydrogels due to their renewability, low cost, biodegradability, biocompatibility, transparency and non-toxicity, so that they can be considered as a substitute for petroleum-based materials in the near future. ${ }^{51}$
The synthesis of hydrogels involves two steps: the dissolution of polymer, and the physical or chemical crosslinking in the presence of a crosslinking agent, resulting in a $3 \mathrm{D}$ structure. ${ }^{52}$ The most common crosslinking agents involved in the synthesis of cellulose-based hydrogels include fumaric acid,$^{53}$ citric acid ${ }^{54}$ oxalic acid and other polycarboxylic acids that form ester linkages with the cellulose; polyethylene glycol diglycidyl ether; ${ }^{55}$ glycerol diglycidyl ether; ${ }^{56}$ epichlorohydrin. ${ }^{57}$

Hydrogels from both native cellulose and its derivatives, including methyl cellulose, hydroxypropyl cellulose, hydroxypropylmethyl cellulose and carboxymethyl cellulose, have been reported ${ }^{58}$ Apart from this, composite hydrogels of cellulose with different polymers like lignin, chitin, poly-vinyl alcohol have been fabricated by blending. ${ }^{51}$ The synthesis of cellulose-inorganic hybrid hydrogels has been carried out, where cellulose nanoparticles were embedded in a biobased matrix. ${ }^{51}$ They find immense applications in food ${ }^{58}$ agriculture, ${ }^{59}$ biomedicine and drug delivery, ${ }^{60}$ sensors ${ }^{61}$ and purification. ${ }^{62}$ Graphenecellulose nanocomposites have also been synthesized for sensing application. ${ }^{63}$

Just like cellulose hydrogels, cellulose-based aerogels have also attracted the attention of researchers in the past few decades. Aerogels are distinct porous materials exhibiting properties such as low density, large surface area per unit mass and satisfactory surface chemical activities. $^{64}$ The structure of these aerogels is affected by the plant source and the method of extraction, since these factors directly affect the crystallinity, thermal stability and degree of polymerization of cellulose. Three steps are involved in their synthesis - dissolution of cellulose, formation of a cellulose gel, and drying of the gel, while retaining its 3D porous structure. ${ }^{65}$ The types of cellulose aerogels include natural cellulose aerogels (nanocellulose aerogels and bacterial cellulose aerogels), regenerated cellulose aerogels, ${ }^{66}$ and aerogels made from cellulose derivatives. ${ }^{67}$ They find wide applications in the areas of adsorption and oil/water separation, absorption, preparation of carbon aerogels, capacitors, biomedicine, and metal nanoparticle/metal oxide carriers etc. ${ }^{64}$

\section{Cellulose nanomaterials or nanocelluloses}

The cellulosic fraction of biomass has been studied extensively to obtain nano-dimensional biomaterials, i.e. materials having at least one 
dimension in the nanometer range. ${ }^{68}$ Cellulose nanomaterials can be of four types: bacterial nanocellulose (BC), microfibrillated cellulose (MFC), cellulose nanofibers (CNFs) and cellulose nanocrystals (CNCs). BC has bacterial origin, while the rest are generally obtained from biomass, thus, the nature of biomass affects the properties of synthesized nanocelluloses. ${ }^{41}$ These nanomaterials are renewable, biocompatible and biodegradable, and exhibit exceptional properties, such as high tensile strength, thermal stability and surface area, as well as low density, but they vary in their dimensions, method of preparation, properties and hence applications. ${ }^{68}$

Mechanical pressure after chemical treatment of biomass can lead to the isolation of MFC. Ultra-refining can be used to defibrillate the cellulose fibers for isolating MFC and CNF. ${ }^{69}$

$\mathrm{CNF}$, the elementary unit of cellulose fibers, are generally 5-60 $\mathrm{nm}$ thick and several micrometers in length. Various methods, i.e. mechanical, chemical or enzymatic, have been reported for their production. ${ }^{16}$ The surface of CNFs can be modified to increase their compatibility within the polymeric matrix. ${ }^{70}$ Cellulose microfibrils contain randomly arranged crystalline and amorphous regions, from which the crystalline regions are extracted to obtain CNCs.

CNCs are rod-shaped, one-dimensional nanomaterials, with the diameter ranging from $100 \mathrm{~nm}$ to several micrometers and limited flexibility. The preparation of CNCs is a two-step process, where the first step is the pretreatment of biomass for the isolation of cellulosic fibers and the second one is the controlled hydrolysis (chemical or enzymatic) to remove the amorphous regions of cellulose. ${ }^{16}$ The amorphous domains of cellulose are more prone to acid hydrolysis by mineral acids $\left(\mathrm{HCl}\right.$ and $\left.\mathrm{H}_{2} \mathrm{SO}_{4}\right)$ than crystalline regions, thereby releasing individual crystalline domains upon hydrolysis, but there is a problem regarding the handling and disposal of concentrated acid. The enzymatic method has also been used for the selective hydrolysis of cellulosic fibers to obtain a high yield, but although it consumes lower energy, it is highly timeconsuming. ${ }^{68}$ Therefore, all the aspects need to be considered for regarding a particular process as economical. CNCs have been also synthesized from commercially available microcrystalline cellulose (MCC), partially depolymerized materials obtained by treating cellulosic fibers with mineral acids, with applications in nutraceutical industries. ${ }^{71}$

The isolation, characterization and applications of nanocellulose in different fields have been reviewed in a number of books and journal articles. ${ }^{16,72,73}$ Solid acid catalysts and transition metal based catalysts have also been used for selective hydrolysis of cellulose to obtain cellulose nanoparticles, which are extensively used in biocomposites and drug carriers. ${ }^{74-76}$

\section{Platform chemicals derived from cellulose}

The cellulose to glucose conversion serves as an intermediate step to synthesize a variety of value-added products. Enzymatic/acid hydrolysis of cellulose results in the production of glucose monomers. The enzymatic reaction is highly specific due to the three constituting enzymes of the cellulase: endoglucanases, exoglucanase and $\beta$-glucosidase. ${ }^{77}$ However, the method has certain disadvantages: the instability of enzymes at high temperature, the high cost involved in their isolation and purification, and difficult recovery. The controlled acid hydrolysis of cellulose using mineral acids is considered an effective method for the production of glucose; however, problems related to corrosion and pollution limit the use of mineral acids. Metal chlorides too have received great attention due to their high catalytic potency, decomposition power and ease of recovery, in comparison with mineral acids. ${ }^{78,79}$ Ionic liquids have been reported to serve as green solvents for converting cellulose directly to various valueadded chemicals. ${ }^{80,81}$ Glucose, obtained after pretreatment of biomass and saccharification of cellulose, may be subjected to various chemical transformations: isomerization, fermentation, hydrogenation and dehydration to obtain desired platform chemicals (Fig. 3).

Glucose $\left(\mathrm{C}_{6} \mathrm{H}_{12} \mathrm{O}_{6}\right)$ can be readily isomerized to its structural isomer fructose by isomerase. This conversion or isomerization has also been reported with Lewis acid and Brønsted base catalysts, ${ }^{82}$ zeolites, ${ }^{83}$ aluminates, green catalysts $e t c{ }^{84}$ The isomerization of glucose to fructose is considered vital for selective synthesis of 5hydroxymethylfurfural (HMF), an important platform chemical.

The cellulose fraction of biomass provides fermentable sugar, i.e. glucose, upon saccharification or hydrolysis. Upon fermentation, glucose produces a variety of alcohols and acids, such as ethanol, lactic acid, propanol, acetone, succinic acid, butanediol and butanol, of which 
ethanol and lactic acid hold primary importance. ${ }^{77}$ Lactic acid is regarded as a basic building block of chemical industry. It not only finds application in the food, pharmaceutical and cosmetic industries, but also serves as a potential feedstock for the manufacture of polylactic acid (PLA), a biodegradable polymer used as environmentally friendly biodegradable plastic.

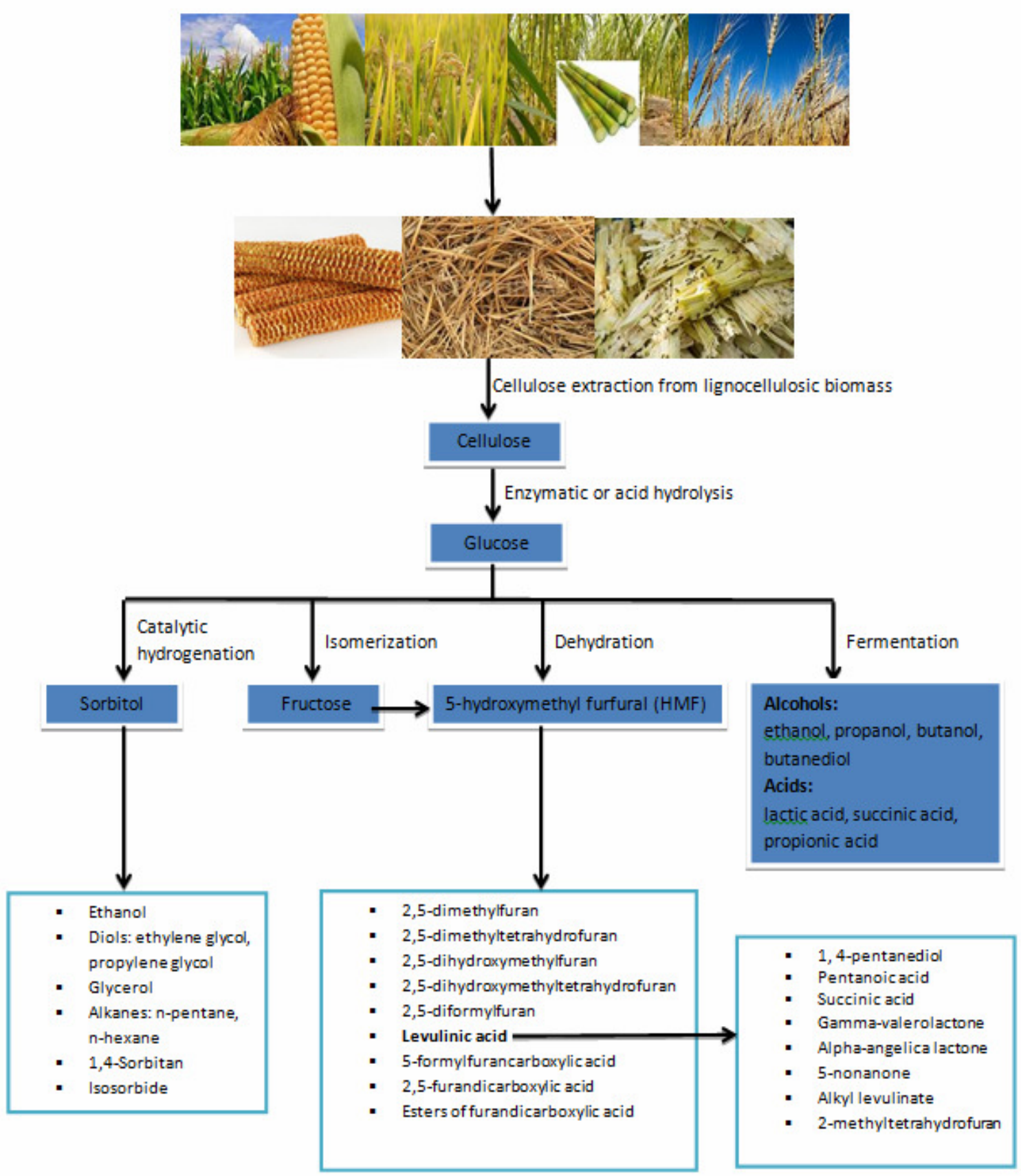

Figure 3: Chemical transformations of cellulose derived glucose to obtain platform chemicals

A catalytic system for selective conversion of cellulose to lactic acid has been reported. ${ }^{85}$

Ethanol, an inexpensive abundantly available liquid, serves as a second-generation liquid transportation biofuel; it is a cleaner fuel in comparison with pure gasoline and diesel, and is used as gasoline additive in order to increase the octane number and improve vehicle emissions 
due to its low boiling point and hygroscopic nature. ${ }^{86}$ Ethanol-based hand sanitizers also find use in the medical and public health care sector. The production of ethanol generally involves three steps, i.e. pretreatment, saccharification and fermentation (Fig. 4), where pretreatment increases the enzymatic digestibility of cellulose, saccharification produces fermentable sugars, which are finally converted to ethanol by microbial fermentation. ${ }^{87}$ Generally, two approaches can be followed to obtain ethanol: separated hydrolysis and fermentation (SHF) or simultaneous saccharification and fermentation (SSF), of which SSF is preferred because it produces a higher concentration of ethanol rapidly and at relatively low cost. ${ }^{88}$ Apart from SSF and SHF, the control bioprocessing (CBP) process enables the production of cellulase, saccharification and fermentation to be carried out in a single step. ${ }^{89}$ Among the existing pretreatments, ILs are gaining interest for producing ethanol. Extensive research has been performed on the conversion of cellulosic biomass to bioethanol using ILs. ${ }^{28,90,91}$

The conversion of cellulose to sorbitol, a sugar alcohol, is recognized as an effective route for valorization of biomass, as it is an important platform molecule for various high value-added chemicals (Fig. 5). It is prepared by catalytic hydrogenation of glucose (Scheme 1). The system containing molecular acids, like $\mathrm{H}_{2} \mathrm{SO}_{4}, \mathrm{HCl}$, or heteropolyacids combined with supported metal catalysts like $\mathrm{Pt}, \mathrm{Pd}$, and $\mathrm{Ru}$, catalyzes the conversion of cellulose to sorbitol effectively. ${ }^{95,96}$
One of the recently developed methods for conversion of cellulose to sorbitol involves the use of ruthenium bifunctional catalyst in a neutral aqueous solution. ${ }^{97}$

HMF is a most promising platform chemical linking biomass and chemicals. It is an important product obtained by dehydration of hexoses; glucose, preferably fructose, undergoes dehydration in acidic conditions to form $\mathrm{HMF}$ (Scheme 2). The synthesis of HMF using ionic liquids in combination with metal salts and catalysts has been reported. ${ }^{81,98} \mathrm{Li}$ et al. $^{99}$ have summarized the synthesis of HMF with homogeneous or heterogeneous catalysts in organic solvents. It can be transformed to many useful acids, aldehydes, alcohols, amines, esters, ethers etc. The use of a metal supported catalyst for hydrogenolysis of HMF to 2,5-dimethylfuran (DMF) has been reported. ${ }^{100} \mathrm{HMF}$ reacts with simple alcohols under acidic conditions to form corresponding ethers. ${ }^{101}$ Monosubstituted and disubstituted ethers, i.e. alkoxymethylfurfurals and bis(alkoxy)methylfurfurals, have been recently reported to be synthesized from fructose in a two-step process from a copper-based catalyst system. ${ }^{102}$ The uncontrolled oxidation and reduction of HMF generates a number of oxidation products (2,5-diformylfuran, 5formylfurancarboxylic acid and 2,5furandicarboxylic acid (FDCA)) and reduction products (2,5-dihydroxymethylfuran, 2,5dihydroxymethyltetrahydrofuran and 2,5dimethyltetrahydrofuran). ${ }^{103}$

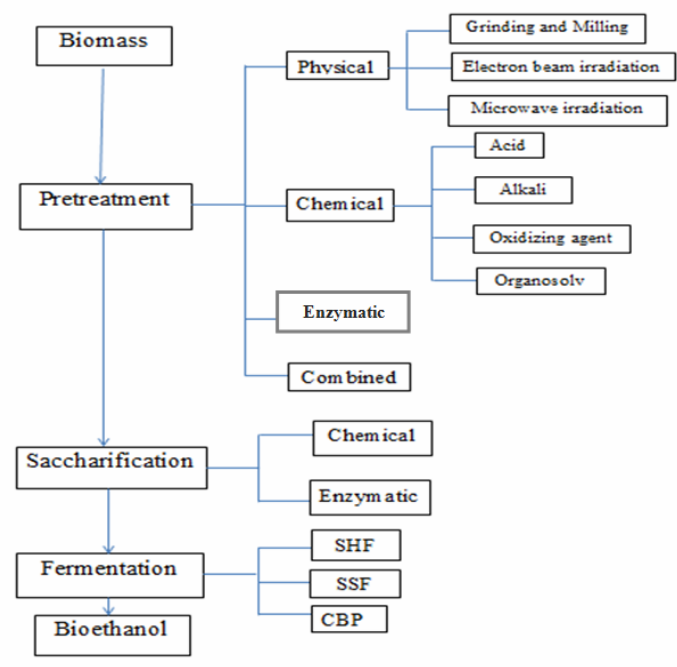

Figure 4: Conversion of biomass to bioethanol ${ }^{87,88}$ 
Cellulose

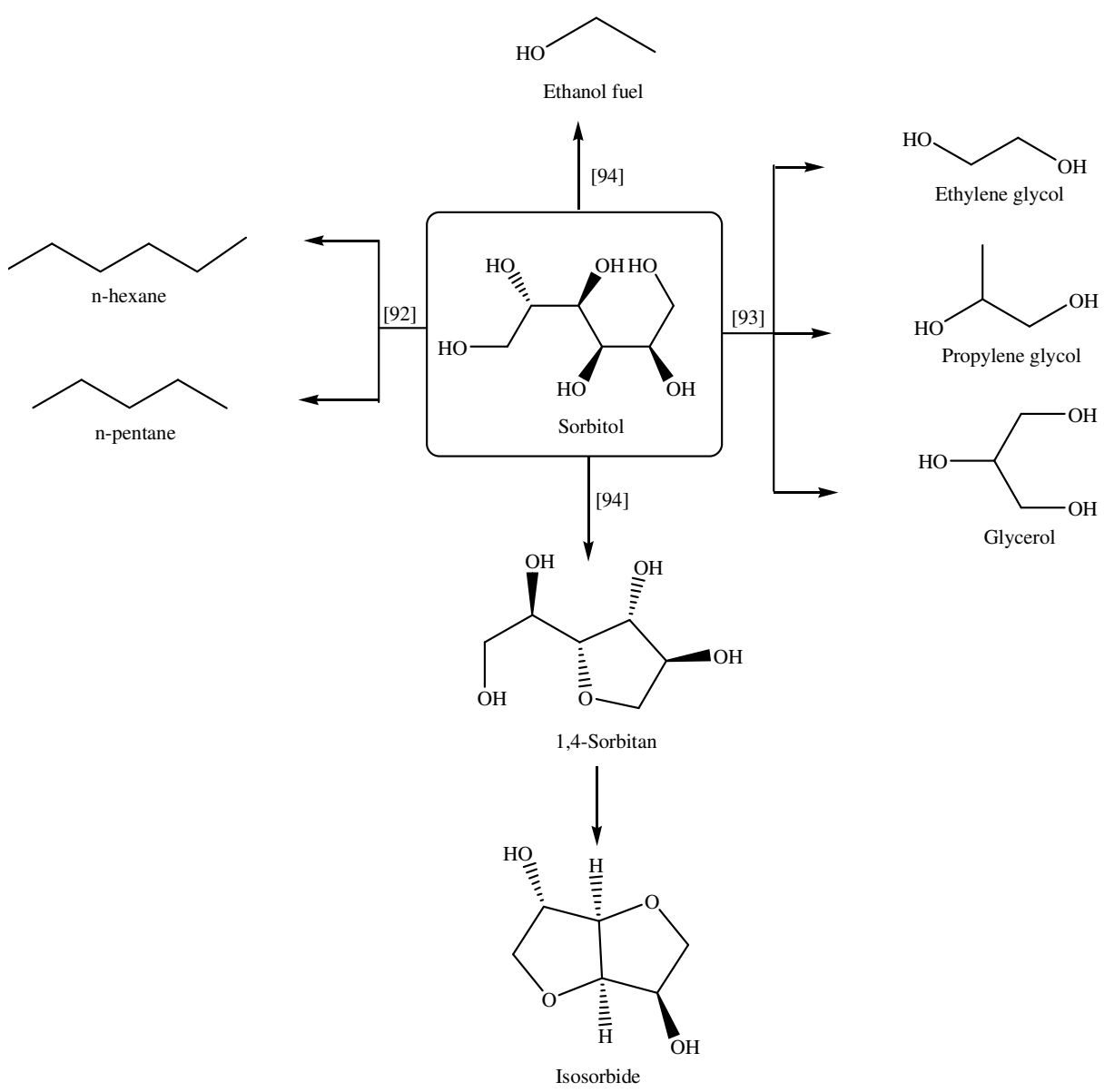

Figure 5: Sorbitol as a precursor to value-added products ${ }^{92-94}$

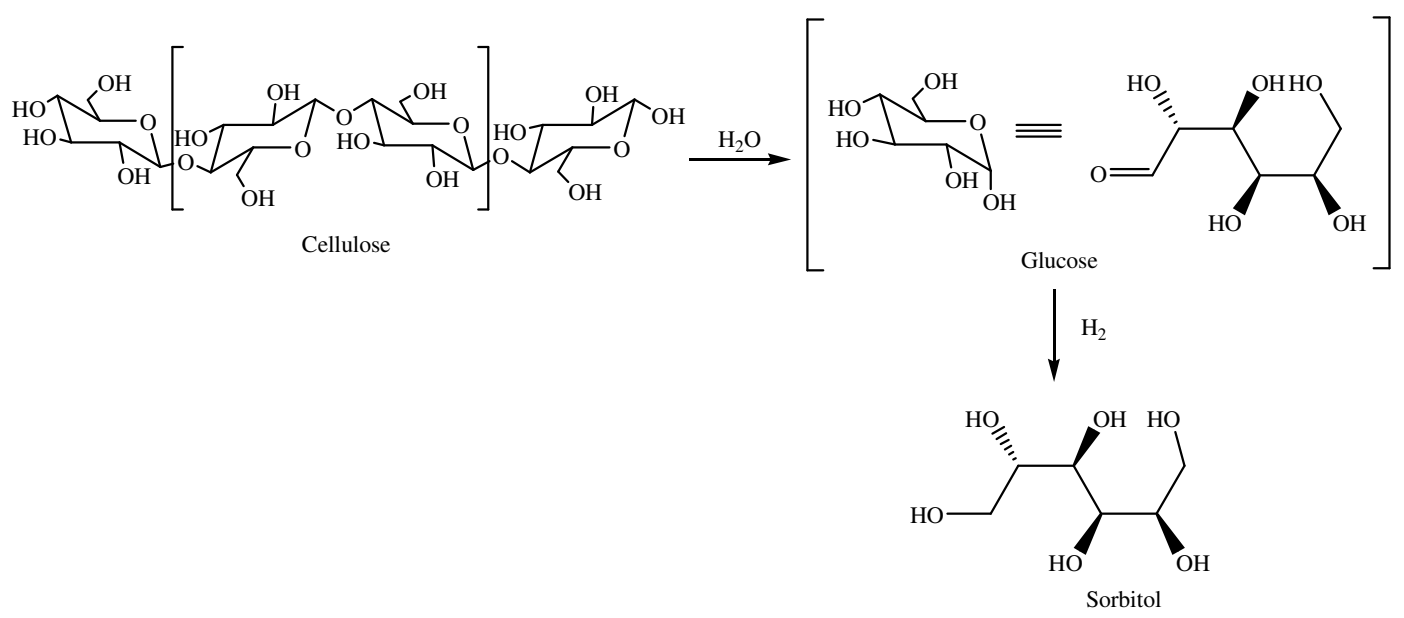

Scheme 1: Conversion of cellulose to sorbitol 


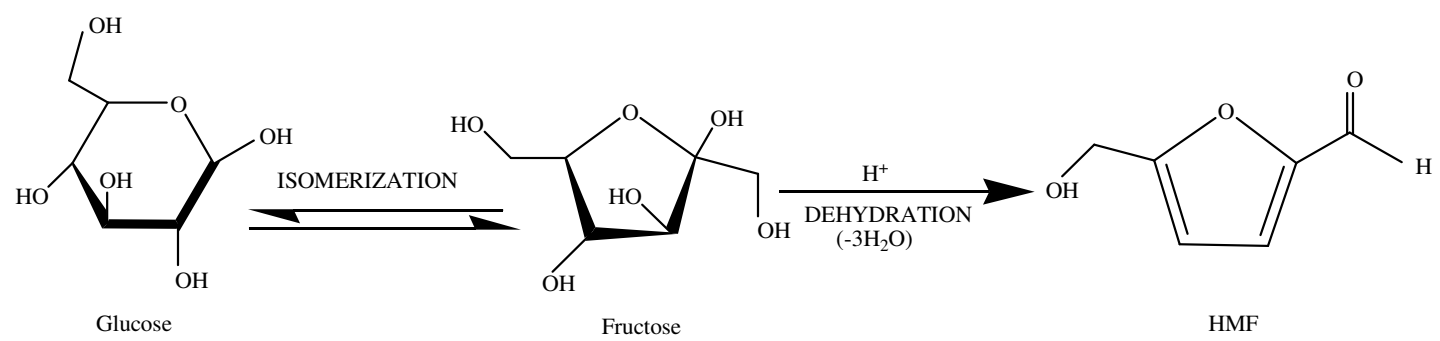

Scheme 2: Acidic dehydration of hexoses to HMF

Table 3

Applications of various commodity chemicals synthesized from HMF

\begin{tabular}{|c|c|}
\hline Chemical & Applications \\
\hline $\mathrm{DMF}^{109}$ & Exhibits excellent solvent properties and is used as biofuel \\
\hline 5-Alkoxymethylfurfural ${ }^{110}$ & Used as fuel or fuel additive \\
\hline 2,5-Diformylfuran ${ }^{111}$ & $\begin{array}{l}\text { Synthesis of polymers, pharmaceuticals, macrocycles and } \\
\text { porpyrines }\end{array}$ \\
\hline 2,5-Dihydroxymethylfuran ${ }^{112}$ & $\begin{array}{l}\text { Synthesis of important chemicals, pharmaceuticals and } \\
\text { polymers }\end{array}$ \\
\hline FDCA $^{113}$ & $\begin{array}{l}\text { Substitute for terephthalic acid in production of polyesters, } \\
\text { monomer for thermoplastic production, serves as fuel } \\
\text { additive and precursor for biodegradable bioplastics }\end{array}$ \\
\hline Arylaminomethyl-2-furanmethanol ${ }^{106}$ & $\begin{array}{l}\text { Natural precursor of photosensitizer in the photodynamic } \\
\text { therapy used in cancer treatment }\end{array}$ \\
\hline Levulinic acid $^{99}$ & $\begin{array}{l}\text { Preparation of pharmaceuticals, dyes, coatings, pesticides, } \\
\text { plastic additives, resins and lubricant additives }\end{array}$ \\
\hline
\end{tabular}

The selective transformation of HMF to 2,5diformylfuran and 2,5-dihydroxymethylfuran can be carried out via the Meerwein Ponndorf Verley Oppenauer (MPVO) reaction, where HMF acts both as oxidant and reductant. ${ }^{104}$

Lai et al..$^{105}$ carried out selective transformation of HMF to 2,5-diformylfuran over vanadium phosphate oxide catalyst. HMF is also used to prepare 5-arylaminomethyl-2furanmethanol through reductive amination. ${ }^{106}$ Dimethyl and diethyl esters of FDCA are reported to be synthesized by the oxidative esterification process. ${ }^{86}$ The formation of ester has also been reported by the use of various homogeneous and heterogeneous catalysts. $^{107}$ Upon acidic hydrolysis, HMF yields levulinic acid, along with formic acid as by-product. The conversion of HMF to levulinic acid/formic acid has been carried out using sulfuric acid as catalyst and $\gamma$ valerolactone as a green solvent. ${ }^{108}$ The different value-added chemicals synthesized from HMF are shown in Figure 6. Various applications of HMF derivatives are discussed in Table 3.
Levulinic acid acts as a starting material to a number of commodity chemicals for diverse applications (Fig. 7). Levulinic esters, used as diesel additives, can be prepared by esterification of levulinic acid with ethanol in the presence of acid $\left(\mathrm{HCl}\right.$ or $\left.\mathrm{H}_{2} \mathrm{SO}_{4}\right)$, but an efficient and green method for synthesis involves the use of heteropolyacids or solid acid catalysts. ${ }^{114,115}$ Recently, the levulinic esters synthesis has been carried out using tin modified silicotungstic acid supported on $\mathrm{Ta}_{2} \mathrm{O}_{5}{ }^{116}$ The hydrogenation of levulinic acid and its esters over solid acid catalysts results in the production of $\gamma$ valerolactone, 1,4-pentanediol and 2-methyl tetrahydrofuran. ${ }^{117-119} \gamma$-Valerolactone is also known to be synthesized by catalytic hydrodeoxygenation of levulinic acid by formation of angelica lactone. ${ }^{120}$ The synthesis of succinic acid from levulinic acid by oxidative demethylation has been reported. ${ }^{121,122}$ Levulinic acid and its derivatives serve as building blocks for polymer industries. ${ }^{123,124}$ 
Cellulose

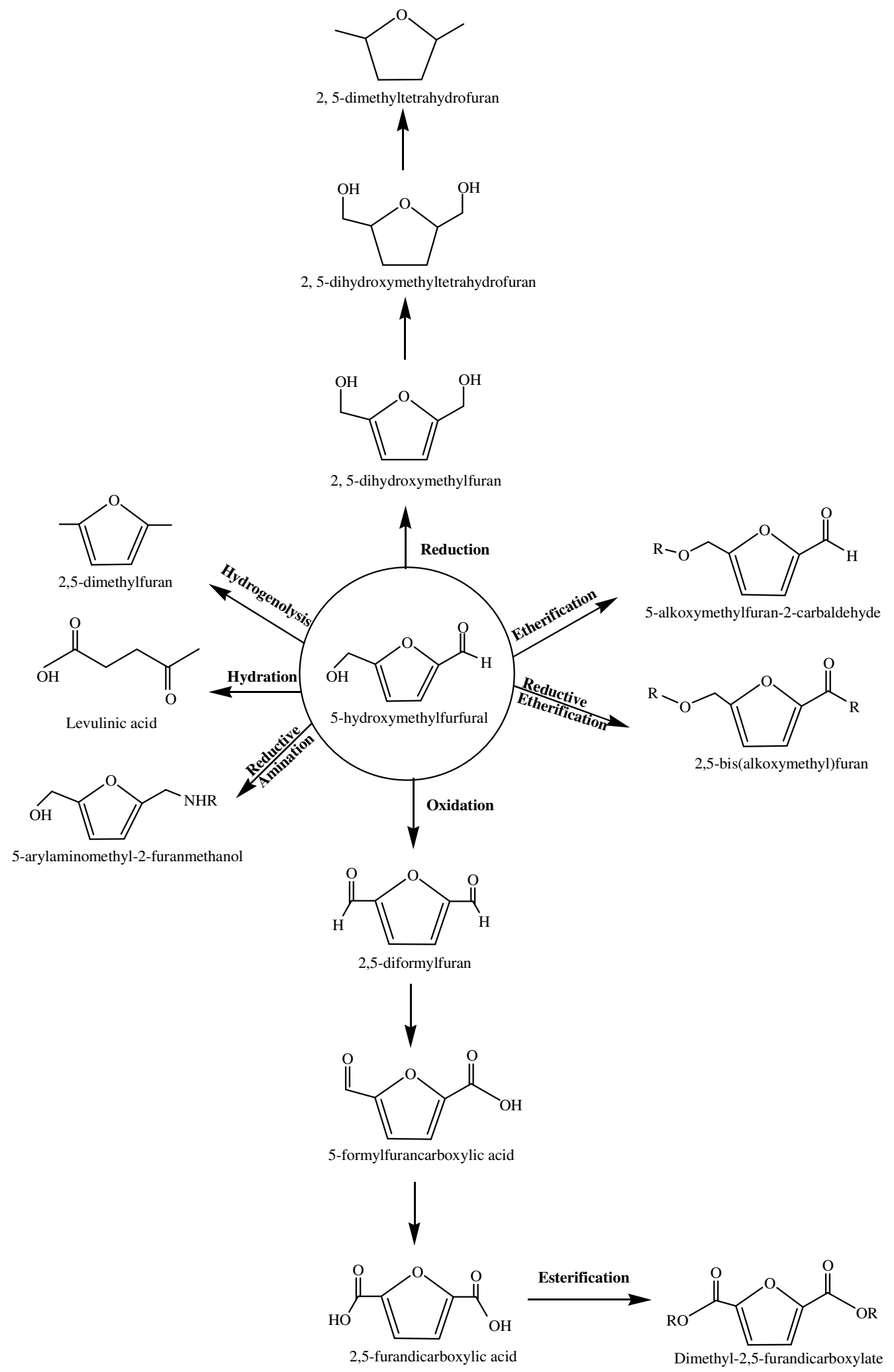

Figure 6: Platform chemicals derived from 5-hydroxymethylfurfural (HMF) 


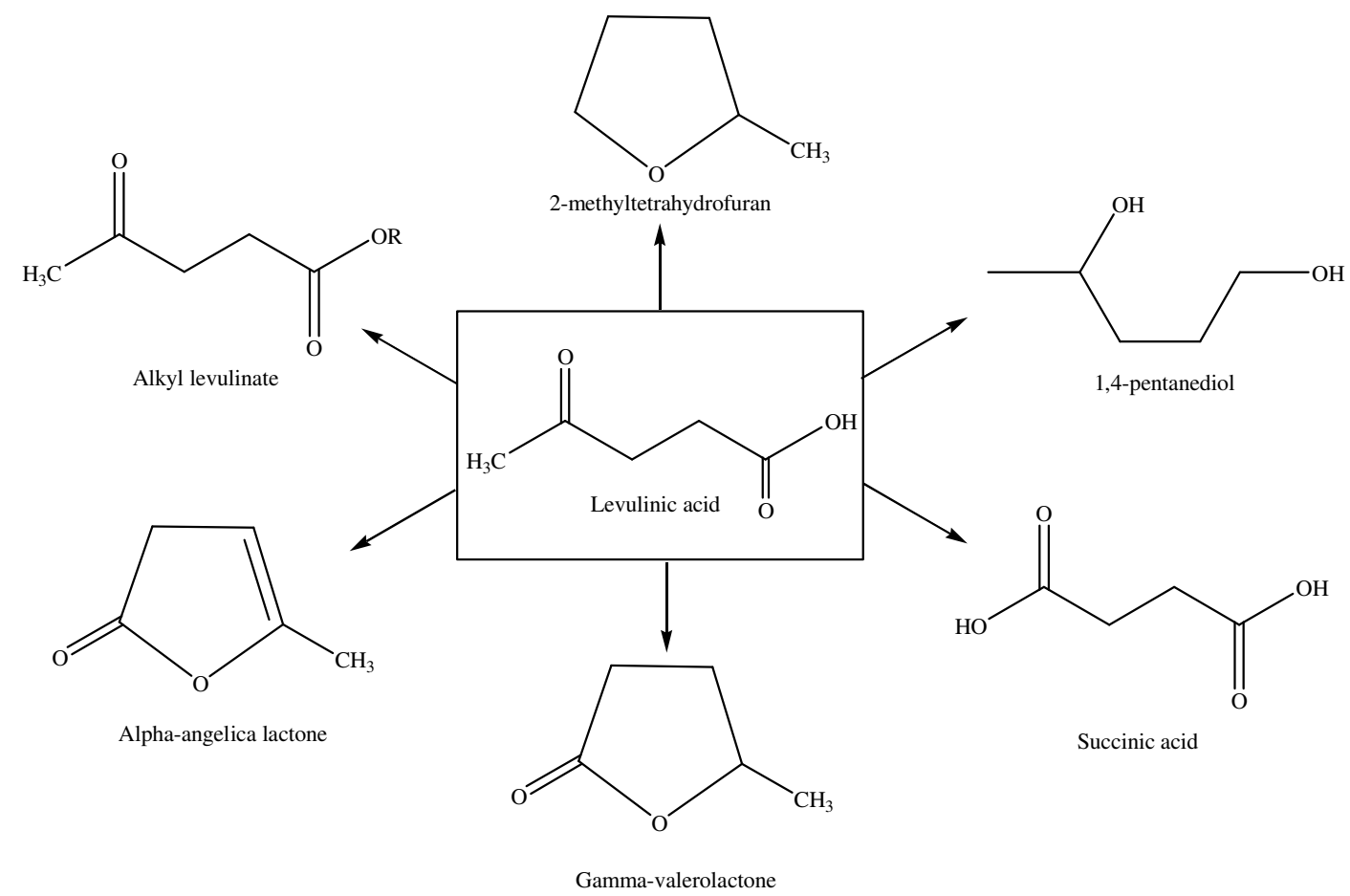

Figure 7: Common value-added commodities obtained from levulinic acid

\section{CONCLUSION}

The isolation of cellulose from lignocellulosic biomass via various pretreatment processes is the foremost step to utilize its potential. The nature of the pretreatment will affect the yield, degree of polymerization and crystallinity of the isolated cellulosic fraction, which, in turn, can be converted into biofuels, chemicals, biopolymers, gels, nanomaterials etc. with extensive applications. Although the production of biofuel from cellulose offers the opportunity to overcome the dependence on depleting energy resources, expensive conversion technologies limit its commercial production. Similarly, a number of methods are available for synthesizing platform chemicals using different reagents, solvent systems and catalysts, but these platform chemicals are produced through competitive processes, where the use of a particular reagent or reaction condition selectively favors the production of one over the other. The challenge is not just achieving a good yield, but attaining a good yield while keeping in view the basic principles of green or sustainable chemistry. Cellulose-based plastics or modified celluloses emerged as a boon for polymer industry, as they can not only decrease the dependence of plastic industries on limited fossil fuel reserves, but also help achieve environmental safety, since there is significant reduction in non-renewable energy consumption and carbon dioxide emission. Although biomass-based plastics offer applications in various fields, new synthesis approaches or modification methods are still required, so that they can compete with conventional fossil fuel-based plastics. The development of novel, green and economical approaches for transforming cellulose-rich biomass feedstocks would contribute to environmental and human health, while sustaining scientific and technological progress, and thus the industries. Also, an emphasis on the integrated approach, where each fraction of biomass is simultaneously valorized, would be revolutionary in obtaining a wide variety of value-added products.

\section{REFERENCES}

1 Global Energy Statistical Yearbook 2019; https://yearbook.enerdata.net/totalenergy/worldconsumption-statistics.html 2 G. De-Bhowmick, A. K. Sarmah and R. Sen, Bioresour. Technol., 247, $1144 \quad$ (2018), https://doi.org/10.1016/j.biortech.2017.09.163

3 A. Yousuf, D. Pirozzi and F. Sannino, in "Lignocellulosic Biomass to Liquid Biofuels", edited by A. Yousuf, D. Pirozzi and F. Sannino, Academic Press, 2020, pp. 1-15 
4 V. Menon and M. Rao, Prog. Energ. Combust., 38, 522 (2012), https://doi.org/10.1016/j.pecs.2012.02.002

F. B. Haffner, V. D. Mitchell, R. A. Arundale and S. Bauer, Cellulose, 20, 1629 (2013), https://doi.org/10.1007/s10570-013-9935-1

6 D. Barana, A. Salanti, M. Orlandi, D. S. Ali and L. Zoia, Ind. Crop. Prod., 86, 31 (2016), https://doi.org/10.1016/j.indcrop.2016.03.029

R. R. C. Bakker, H. W. Elbersen, R. P. Poppens and J. P. Lesschen, "Rice Straw and Wheat StrawPotential Feedstocks for the Biobased Economy", NL Agency, 2013

${ }^{8}$ M. Pointner, P. Kuttner, T. Obrlik, A. Jager and H. Kahr, Agron. Res., 12, 391 (2014)

9 R. Kaur and S. K. Uppal, Colloid Polym. Sci., 293, 2585 (2015), https://doi.org/10.1007/s00396-0153653-1

10 P. Kaur, S. K. Uppal, C. Dhir, P. Sharma and R. Kaur, Sugar Tech., 17, 412 (2015), https://doi.org/10.1007/s12355-014-0346-x

11 S. Nanda, J. A. Kozinski and K. Dalai, Curr. Biochem. Eng., 3, 24 (2016)

12 W. Den, V. K. Sharma, M. Lee, G. Nadadur and R. S. Varma, Front. Chem., 6, 141 (2018), https://doi.org/10.3389/fchem.2018.00141

13 S. S. Hassan, G. A. Williams and A. K. Jaiswal, Bioresour. Technol., 262, $310 \quad$ (2018), https://doi.org/10.1016/j.biortech.2018.04.099

14 H. K. Sharma, C. Xu and W. Qin, Waste Biomass Valorif., $\quad \mathbf{1 0}, \quad 235 \quad$ (2019), https://doi.org/10.1007/s12649-017-0059-y

15 D. W. O'Connell, C. Birkinshaw and T. F. O'Dwyer, Bioresour. Technol., 99, 6709 (2008), https://doi.org/10.1016/j.biortech.2008.01.036

16 R. J. Moon, A. Martini, J. Nairn, J. Simonsen and J. Youngblood, Chem. Soc. Rev., 40, 3941 (2011), https://doi.org/10.1039/C0CS00108B

17 B. Xiong, P. Xhao, P. Cai, L. Zhang, K. Hu et al., Cellulose, 20, $613 \quad$ (2013), https://doi.org/10.1007/s10570-013-9869-7

18 B. Xiong, P. Zhao, K. Hu, L. Zhang and G. Cheng, Cellulose, 21, $1183 \quad$ (2014), https://doi.org/10.1007/s10570-014-0221-7

19 M. Isik, H. Sardon and D. Mecerreyes, Int. J. Mol. Sci., $\quad \mathbf{1 5}, \quad 11922 \quad$ (2014), https://doi.org/10.3390/ijms150711922

20 N. Johar, I. Ahmad and A. Dufresne, Ind. Crop. $\begin{array}{llll}\text { Prod., } & 37, & 93 & \text { (2012), }\end{array}$ https://doi.org/10.1016/j.indcrop.2011.12.016

21 S. M. Rosa, N. Rehman, M. I. G. de Miranda, S. M. Nachtigall and C. I. Bica, Carbohyd. Polym., 87, 1131 (2012), https://doi.org/10.1016/j.carbpol.2011.08.084

22 M. A. Abdullah, M. S. Nazir, M. R. Raza, B. A. Wahjoedi and A. W. Yussof, J. Clean. Prod., 126, 686 (2016), https://doi.org/10.1016/j.jclepro.2016.03.107

23 E. Galiwango, N. S. A. Rahman, A. H. AlMarzouqi and A. A. Khaleel, Heliyon, 5, e02937 (2019), https://doi.org/10.1016/j.heliyon.2019.e02937
24 Y. Li, J. Wang, X. Liu and S. Zhang, Chem. Sci., 9, 4027 (2018), https://doi.org/10.1039/C7SC05392D

25 Z. Usmani, M. Sharma, P. Gupta, Y. Karpichev, N. Gathergood et al., Bioresour. Technol., 304, 123003 (2020), https://doi.org/10.1016/j.biortech.2020.123003 26 V. Rigual, T. M. Santos, J. C. Dominguez, M. V. Alonso, M. Oliet et al., Biomass Bioenerg., 117, 190 (2018), https://doi.org/10.1016/j.biombioe.2018.07.014 27 S. Arora, N. Gupta and V. Singh, Waste Biomass Valorif., $\quad \mathbf{1 1}, \quad 3345 \quad$ (2020), https://doi.org/10.1007/s12649-019-00603-2

28 R. Yamada, K. Nakashima, N. Asai-Nakashima, W. Tokuhara, N. Ishida et al., Appl. Biochem. Biotechnol., $\quad 182, \quad 229 \quad$ (2017), https://doi.org/10.1007/s12010-016-2322-2

29 F. Gironi and V. Piemonte, Energ. Source Part A, 33, 1949

(2011), https://doi.org/10.1080/15567030903436830

30 E. B. Arikan and H. D. Ozsoy, J. Civ. Eng. Arch., 9, 188 (2015), https://doi.org/10.17265/19347359/2015.02.007

31 F. Bilo, S. Pandini, L. Sartore, L. E. Depero, G. Gargiulo et al., J. Clean. Prod., 200, 357 (2018), https://doi.org/10.1016/j.jclepro.2018.07.252

$32 \mathrm{H}$. Shaghaleh, X. Xu and S. Wang, $R S C A d v$., 8, 825 (2018), https://doi.org/10.1039/C7RA11157F

33 R. G. Candido and A. R. Gonçalves, Carbohyd. Polym., $\quad$ 152, $679 \quad$ (2016), https://doi.org/10.1016/j.carbpol.2016.07.071

34 M. Crabbe-Mann, D. Tsaoulidis, M. Parhizkar and M. Edirisinghe, Cellulose, 25, 1687 (2018), https://doi.org/10.1007/s10570-018-1673-y

35 Y. A. Gismatulina, V. V. Budaeva and G. V. Sakovich, Russ. Chem. Bull., 65, 2920 (2017), http://dx.doi.org/10.1007\%2Fs11172-016-1678-3

36 B. Muhitdinov, T. Heinze, N. Normakhamatov and A. Turaev, Carbohyd. Polym., 173, 631 (2017), https://doi.org/10.1016/j.carbpol.2017.06.033

37 S. Kumar and Y. K. Walia, Asian J. Adv. Basic Sci., 5, 109 (2017)

38 G. Joshi, V. Rana, S. Naithani, V. K. Varshney, A. Sharma et al., Carbohyd. Polym., 223, 115082 (2019), https://doi.org/10.1016/j.carbpol.2019.115082

39 M. F. Li, S. N. Sun, F. Xu and R. C. Sun, Eur. $\begin{array}{llll}\text { Polym. } & \text { J., } & \text { 7, } & 1817\end{array}$ https://doi.org/10.1016/j.eurpolymj.2011.06.013

40 T. Wüstenberg, in "Cellulose and Cellulose Derivatives in the Food Industry: Fundamentals and Applications", John Wiley \& Sons, Germany, 2014, pp. 185

41 S. Hokkanen, A. Bhatnagar and M. Sillanpää, Water Res., 91, $156 \quad$ (2016), https://doi.org/10.1016/j.watres.2016.01.008

42 D. Chen and T. G. van de Ven, Cellulose, 23, 1051 (2016), http://doi.org/10.1007/s10570-016-0862-9

43 E. B. Strong, C. W. Kirschbaum, A. W. Martinez and N. W. Martinez, Cellulose, 25, 3211 (2018), https://doi.org/10.1007/s10570-018-1805-4 
44 G. B. Martins, M. R. D. Santos, M. V. Rodrigues, R. R. Sucupira, L. Meneghetti et al., J. Braz. Chem. Soc., 28, 2064 (2017), http://dx.doi.org/10.21577/0103-5053.20170051

45 A. Isogai, T. Hänninen, S. Fujisawa and T. Saito, Prog. Polym. Sci., 86, $122 \quad$ (2018), https://doi.org/10.1016/j.progpolymsci.2018.07.007

46 C. Chang and L. Zhang, Carbohyd. Polym., 84, 40 (2011), https://doi.org/10.1016/j.carbpol.2010.12.023

47 J. Shokri and K. Adibkia, in "Cellulose - Medical, Pharmaceutical and Electronic Applications", edited by T. G. M. Van De Ven, IntechOpen, 2013, pp. 47, https://doi.org/10.5772/3470

48 L. Wojnárovits, C. M. Földváry and E. Takács, Radiat. Phys. Chem., 79, $848 \quad$ (2010), https://doi.org/10.1016/j.radphyschem.2010.02.006

${ }^{49}$ S. Wohlhauser, G. Delepierre, M. Labet, G. Morandi, W. Thielemans et al., Macromolecules, 51, 6157 (2018),

https://doi.org/10.1021/acs.macromol.8b00733

50 M. Miloslav, in "Pulp Production and Processing: From Papermaking to High-Tech Products", edited by V. Popa, Smithers Rapra, United Kingdom, 2013, pp. 166-174

51 N. A. Peppas and A. S. Hoffman, in "Biomaterials Science", edited by W. R. Wagner, G. Zhang, S. E. Sakiyama-Elbert and M. J. Yaszemski, Academic Press, 2020, pp. 153-166

52 X. Shen, J. L. Shamshina, P. Berton, G. Gurau and R. D. Rogers, Green Chem., 18, 53 (2016), https://doi.org/10.1039/C5GC02396C

53 M. Dilaver and K. Yurdakoc, Polym. Bull., 73, 2661 (2016), https://doi.org/10.1007/s00289-0161613-7

54 M. G. Raucci, M. A. Alvarez-Perez, C. Demetri, D. Giugliano, V. De Benedictis et al., J. Biomed. Mater. Res. A, 103, $2045 \quad$ (2015), https://doi.org/10.1002/jbm.a.35343

55 H. Kono, Carbohyd. Polym., 106, 84 (2014), https://doi.org/10.1016/j.carbpol.2014.02.020

56 J. Li, L. Fang, W. R. Tait, L. Sun, L. Zhao et al., RSC Adv., 7, $\quad 54823 \quad$ (2017), https://doi.org/10.1039/C7RA10788A

57 D. Ciolacu, C. Rudaz, M. Vasilescu and T. Budtova, Carbohyd. Polym., 151, 392 (2016), https://doi.org/10.1016/j.carbpol.2016.05.084

58 C. Demitri, R. Del Sole, F. Scalera, A. Sannino, G. Vasapollo et al., J. Appl. Polym. Sci., 110, 2453 (2008), https://doi.org/10.1002/app.28660

59 C. Demitri, F. Scalera, M. Madaghiele, A. Sannino and A. Maffezzoli, Int. J. Polym. Sci., 1 (2013), https://doi.org/10.1155/2013/435073

60 A. S. Hoffman, Adv. Drug Deliv. Rev., 64, 18 (2012), https://doi.org/10.1016/j.addr.2012.09.010

61 J. Tavakoli and Y. Tang, Polymers, 9, 364 (2017), https://doi.org/10.3390/polym9080364

62 K. Bethke, S. Palantöken, V. Andrei, M. Roß, V. S. Raghuwanshi et al., Adv. Funct. Mater., 28, 1800409 (2018), https://doi.org/10.1002/adfm.201800409
63 Y. Chen, P. Pötschke, J. Pionteck, B. Voit and H. Qi, J. Mater. Chem. A, 6, 7777 (2018), https://doi.org/10.1039/C8TA00618K

${ }^{64}$ L. Y. Long, Y. X. Weng and Y. Z. Wang, Polymers, 10, 623 (2018), https://doi.org/10.3390/polym10060623

65 S. Lee, M. J. Jeong and K. Y. Kang, J. Korean Phys. Soc., 67, $738 \quad$ (2015), https://doi.org/10.3938/jkps.67.738

${ }^{66}$ Q. Y. Mi, S. R. Ma, J. Yu, J. S. He and J. Zhang, ACS Sustain. Chem. Eng., 4, 656 (2016), https://doi.org/10.1021/acssuschemeng.5b01079

67 M. Yu, J. Li and L. Wang, Chem. Eng. J., 310, 300 (2017), https://doi.org/10.1016/j.cej.2016.10.121

${ }^{68}$ M. Park, S. Shin, J. Cheng and J. Hyun, Carbohyd. Polym., $\quad 158, \quad 133 \quad$ (2017), https://doi.org/10.1016/j.carbpol.2016.12.007

${ }^{6}$ G. L. Berto, V. Arantes, Int. J. Biol. Macromol., 127, 637 (2019) https://doi.org/10.1016/j.ijbiomac.2019.01.169

${ }^{70}$ A. Blanco, M. C. Monte, C. Campano, A. Balea, N. Merayo et al., in "Handbook of Nanomaterials for Industrial Applications", edited by C. M. Hussain, Elsevier, 2018, pp. 74-126

71 L. Brinchi, F. Cotana, E. Fortunati and J. M. Kenny, Carbohyd. Polym., 94, 154 (2013), https://doi.org/10.1016/j.carbpol.2013.01.033

${ }^{72}$ A. Kardam, K. R. Raj, S. Srivastava and M. M. Srivastava, Clean Technol. Environ. Policy, 16, 385 (2014), http://doi.org/ 10.1007/s10098-013-0634-2

73 A. W. Carpenter, C. F. de Lannoy and M. R. Wiesner, Environ. Sci. Technol., 49, 5277 (2015), https://doi.org/10.1021/es506351r

74 D. Ciolacu and V. Popa, in "Pulp Production and Processing High-Tech Application", edited by V. Popa, $2^{\text {nd }}$ edition, De Gruyter, 2020

75 Z. Zhou, C. Lu, X. Wu and X. Zhang, RSC Adv., 3, 26066 (2013), https://doi.org/10.1039/C3RA43006E

76 H. Du, C. Liu, X. Mu, W. Gong, D. Lv et al., Cellulose, 23, 2389 (2016), https://doi.org/10.1007/s10570-016-0963-5

77 B. Agarwal, V. Ahluwalia, A. Pandey, R. S. Sangwan and S. Elumalai, in "Biofuels", edited by A. K. Agarwal, R. A. Agarwal, T. Gupta and B. R. Gurjar, Springer, Singapore, 2017, pp. 7-33

78 M. Zuo, Z. Li, Y. Jiang, X. Tang, X. Zeng et al., $\begin{array}{lllll}R S C & A d v ., & \mathbf{6} & 27004 & \text { (2016), }\end{array}$ https://doi.org/10.1039/C6RA90032A

79 S. Dutta, S. De, M. I. Alam, M. M. Abu-Omar and B. Saha, J. Catal., 288, 8 (2012), https://doi.org/10.1016/j.jcat.2011.12.017

80 J. Song, H. Fan, J. Ma and B. Han, Green Chem., 15, 2619 (2013), https://doi.org/10.1039/C3GC41141A ${ }_{81}$ L. Zhou, R. Liang, Z. Ma, T. Wu and Y. Wu, Bioresour. Technol., 129, $450 \quad$ (2013), https://doi.org/10.1016/j.biortech.2012.11.015

82 C. Liu, J. M. Carraher, J. L. Swedberg, C. R. Herndon, C. N. Flietman et al., ACS Catal., 4, 4295 (2014), https://doi.org/10.1021/cs501197w 
83 S. Saravanamurugan, M. Paniagua, J. A. Melero and A. Riisager, J. Am. Chem. Soc., 135, 5246 (2013), https://doi.org/10.1021/ja400097f

${ }_{84}$ Q. Yang, M. Sherbahn and T. Runge, ACS Sustain. Chem. Eng., 4, $3526 \quad$ (2016), https://doi.org/10.1021/acssuschemeng.6b00587

${ }_{85}$ S. Li, W. Deng, Y. Li, Q. Zhang and Y. Wang, J. Energ. Chem., 32, $138 \quad$ (2019), https://doi.org/10.1016/j.jechem.2018.07.012

${ }^{86}$ S. K. Uppal, R. Kaur, P. Kaur and C. Dhir, Indian J. Chem. Technol., 23, 412 (2016)

${ }^{87}$ X. Zhuang W. Wang, Q. Yu, W. Qi, Q. Wang et al., Bioresour. Technol., 199, 68 (2016), https://doi.org/10.1016/j.biortech.2015.08.051

88 D. P. Maurya, A. Singla and S. Negi, 3 Biotech, 5, 597 (2015), https://doi.org/10.1007/s13205-015-02794

89 P. Binod, R. Sindhu, R. R. Singhania, S. Vikram, L. Devi et al., Bioresour. Technol., 101, 4767 (2010), https://doi.org/10.1016/j.biortech.2009.10.079

90 R. Alayoubi, N. Mehmood, E. Husson, A. Kouzayha, M. Tabcheh et al., Renew. Energ., 145, 1808

https://doi.org/10.1016/j.renene.2019.07.091

(2020),

91 S. Kahani, M. Shafiei, A. Abdolmaleki and K. Karimi, J. Clean. Prod., 168, 952 (2017), https://doi.org/10.1016/j.jclepro.2017.09.008

92 Q. Zhang, T. Wang, Y. Xu, Q. Zhang and L. Ma, Energ. Convers. Manage., 77, 262 (2014), https://doi.org/10.1016/j.enconman.2013.09.032

93 X. Chen, X. Wang, S. Yao and X. Mu, Catal. Commun., $\quad 39, \quad 86 \quad$ (2013), https://doi.org/10.1016/j.catcom.2013.05.012

94 H. Kobayashi, H. Ohta and A. Fukuoka, Catal. Sci. $\begin{array}{llll}\text { Technol., } & \mathbf{2}, & 869 & \text { (2012), }\end{array}$ https://doi.org/10.1039/C2CY00500J

95 A. Anand, R. D. Kulkarni and V. V. Gite, Prog. Org. Coat., 74, $764 \quad$ (2012), https://doi.org/10.1016/j.porgcoat.2011.09.031

96 R. Palkovits, K. A. M. Tajvidi and J. Procelewska, Chem. Commun., 47, $576 \quad$ (2011), https://doi.org/10.1039/C0CC02263B

97 Z. Li, Y. Liu, C. Liu, S. Wu and W. Wei, Bioresour. Technol., 274, $190 \quad$ (2019), https://doi.org/10.1016/j.biortech.2018.11.089

98 L. Zhou, S. Zhang, Z. Li, Z. Zhang, R. Liu et al., Carbohyd. Polym., 212, $289 \quad$ (2019), https://doi.org/10.1016/j.carbpol.2019.02.050

99 X. Li, R. Xu, J. Yang, S. Nie, D. Liu et al., Ind. Crop. $\quad$ Prod., 130, $184 \quad$ (2019), https://doi.org/10.1016/j.indcrop.2018.12.082

100 B. S. Solanki and C. V. Rode, J. Saudi Chem. Soc., 23, 439

(2019),

https://doi.org/10.1016/j.jscs.2018.08.009

${ }^{101}$ M. Balakrishnan, E. R. Sacia and A. T. Bell, Green Chem., 14, $1626 \quad$ (2012), https://doi.org/10.1039/C2GC35102A
102 J. Wei, T. Wang, X. Cao, H. Liu, X. Tang et al., Appl. Catal. B: Environ., 258, 117793 (2019), https://doi.org/10.1016/j.apcatb.2019.117793

${ }^{103}$ Y. Nakagawa, M. Tamura and K. Tomishige, ACS Catal., $\quad 3, \quad 2655 \quad$ (2013), https://doi.org/10.1021/cs400616p

104 J. Wei, T. Wang, P. Tang, X. Tang, Y. Sun et al., Curr. Org. Chem., 23, $2155 \quad$ (2019), https://doi.org/10.2174/1385272823666190802095801

${ }^{105}$ J. Lai, K. Liu, S. Zhou, D. Zhang, X. Liu et al., $\begin{array}{lllll}R S C & A d v ., & 9 & & \end{array}$ https://doi.org/10.1039/C9RA02213A

106 A. Cukalovic and C. V. Stevens, Green Chem., 12, 1201 (2010), https://doi.org/10.1039/C002340J

107 F. Li, X. L. Li, C. Li, J. Shi and Y. Fu, Green Chem., 20, 3050 (2018), https://doi.org/10.1039/C8GC01393D

${ }^{108}$ L. Qi, Y. F. Mui, S. W. Lo, M. Y. Lui, G. R. Akien et al., ACS Catal., 4, 1470 (2014), https://doi.org/10.1021/cs401160y

109 Y. Román-Leshkov, C. J. Barrett, Z. Y. Liu and J. A. Dumesic, Nature, 447, 982 (2007), https://doi.org/10.1038/nature05923

${ }^{110}$ G. J. M. Gruter and F. Dautzenberg, Eur. Pat. Appl., EP 1834950-A1 (2007)

111 A. S. Amarasekara, D. Green and E. McMillan, Catal. Commun., 9, $286 \quad$ (2008), https://doi.org/10.1016/j.catcom.2007.06.021

${ }^{112}$ M. Chatterjee, T. Ishizaka and H. Kawanami, Green Chem., 16, $4734 \quad$ (2014), https://doi.org/10.1039/C4GC01127A

${ }^{113}$ E. de Jong, M. A. Dam, L. Sipos and G. J. Gruter, in "Biobased Monomers, Polymers, and Materials", edited by P. B. Smith and R. A. Gross, American Chemical Society, 2012, pp. 1-13

${ }^{114}$ K. Y. Nandiwale, S. K. Sonar, P. S. Niphadkar, P. N. Joshi, S. S. Deshpande et al., Appl. Catal. A-Gen., 460 90

(2013),

https://doi.org/10.1016/j.apcata.2013.04.024

115 N. Lucas, L. Gurrala and A. Athawale, J. Porous Mater., 26, $\quad 1335 \quad$ (2019), https://doi.org/10.1007/s10934-019-00734-w

${ }^{116}$ P. Ganji and S. Roy, Catal. Commun., 134, 105864 (2020), https://doi.org/10.1016/j.catcom.2019.105864

${ }^{117}$ L. Corbel-Demailly, A. Wilhelm, A. Cabiac, E. Guillon, M. Besson et al., Procs. $26^{\text {th }}$ Biennial Organic Reactions Catalysis Society Conference, Miami, United States, March, 2016

118 I. Obregón, I. Gandarias, M. G. Al-Shaal, C. Mevissen, P. L. Arias et al., Chem. Sus. Chem., 9, 2488 (2016), https://doi.org/10.1002/cssc.201600751

${ }^{119}$ G. Novodárszki, H. E. Solt, J. Valyon, F. Lonyi, J. Hancsok et al., Catal. Sci. Technol., 9, 2291 (2019), https://doi.org/10.1039/C9CY00168A

${ }^{120}$ O. Mamun, M. Saleheen, J. Q. Bond and A. Heyden, J. Phys. Chem. C, 121, 18746 (2017), https://doi.org/10.1021/acs.jpcc.7b06369 
${ }^{121}$ R. Kawasumi, S. Narita, K. Miyamoto, K. I. Tominaga, R. Takita et al., Sci. Rep., 7, 1 (2017), https://www.X-mol.com/paperRedirect/503964

122 D. Carnevali, M. G. Rigamonti, T. Tabanelli, G. S. Patience and F. Cavani, Appl. Catal. A-Gen., 563, 98 (2018), https://doi.org/10.1016/j.apcata.2018.06.034
123 A. S. Amarasekara and S. A. Hawkins, Eur. Polym. $J$. 47 , 2451

https://doi.org/10.1016/j.eurpolymj.2011.09.007

${ }^{124}$ M. Hartweg and C. R. Becer, in "Green Polymer Chemistry: New Products, Processes and Applications", edited by H. N. Cheng, R. A. Gross and P. B. Smith, American Chemical Society, 2018, pp. 331-338 